Relations industrielles

Industrial Relations

\title{
R. BLANPAIN : Principes de droit du travail. Bruges-Bruxelles, La Charte, 1984, 313 pp., ISBN 90-6400-029-0
}

\section{Pierre Verge}

Volume 40, numéro 2, 1985

URI : https://id.erudit.org/iderudit/050144ar

DOI : https://doi.org/10.7202/050144ar

Aller au sommaire du numéro

Éditeur(s)

Département des relations industrielles de l'Université Laval

ISSN

0034-379X (imprimé)

1703-8138 (numérique)

Découvrir la revue

Citer ce compte rendu

Verge, P. (1985). Compte rendu de [R. BLANPAIN : Principes de droit du travail. Bruges-Bruxelles, La Charte, 1984, 313 pp., ISBN 90-6400-029-0]. Relations industrielles / Industrial Relations, 40(2), 403-405.

https://doi.org/10.7202/050144ar

Tous droits réservés @ C Département des relations industrielles de l'Université Laval, 1985
Ce document est protégé par la loi sur le droit d'auteur. L’utilisation des services d'Érudit (y compris la reproduction) est assujettie à sa politique d'utilisation que vous pouvez consulter en ligne.

https://apropos.erudit.org/fr/usagers/politique-dutilisation/ 


\section{RECENSIONS BOOK REVIEWS}

Principes de droit du travail, par $R$. Blanpain, Bruges-Bruxelles, La Charte, 1984, 313 pages, ISBN 90-6400-029-0

Les principes du droit du travail belge, M. Le professeur Blanpain les enseigne depuis une vingtaine d'années à la Faculté de droit de Leuven. Concise synthèse - ainsi, l'ouvrage ne comporte pas de références à la doctrine, mais seulement des références aux arrêts les plus importants de la Cour de Cassation - , ces pages constituent un exposé fort éclairant de ce droit national. Des considérations générales y précèdent la dichotomie classique, droit individuel et droit collectif du travail.

Ces considérations liminaires réunissent, à côté de précisions plus usuelles, des éléments révélateurs tant de l'identité profonde du droit du travail belge que de sa nécessaire adaptation aux contextes nouveaux du travail subordonné. Ces changements sont souvent eux-mêmes le fruit d'influences trans-nationales auxquelles l'auteur se montre particulièrement sensible. Ainsi, l'évolution historique, après des grandes périodes successives de libéralisme, d'interventionnisme, de percée du syndicalisme, débouche-t-elle sur un après-guerre qui évolue lui-même d'une collaboration relativement poussée entre organisations d'employeurs et de travailleurs, à une mise en cause de celle-ci, puis, surtout, à des années de tentatives gouvernementales de sauvegarde de l'emploi. La crise économique actuelle semble en effet avoir quelque peu paralysé ces rapports entre partenaires sociaux, jusque-là relativement poussés et fructueux. Nécessité, particulièrement ressentie en Belgique, de s'assurer de l'harmonie des mesures internes et de l'évolution d'un cadre européen plus large; besoin aussi de tenir compte du pou- voir croissant des multinationales. Le travail se transforme sous l'effet des technologies nouvelles qui, «non seulement favoriseront l'internationalisation de l'économie et renforceront encore la centralisation du pouvoir de décision des entreprises multinationales» ( $p$. 304), mais amèneront une plus grande ubiquité d'exécution. Ces pages introductives nous livrent également, des données plus spécifiques: l'énoncé de la hiérarchie des sources du droit du travail belge (que l'on ne pourra véritablement saisir qu'à la suite de l'exposé subséquent du particularisme des modes de négociation collective qui prévalent dans le pays en cause), les prescriptions détaillées relatives à l'emploi des langues dans les relations de travail.

La partie consacrée au droit individuel du travail est, quantitativement, la plus importante du précis et sans doute aussi celle qui paraîtra la plus classique: exposé des conditions de validité du contrat, analyse des obligations respectives des parties, situations de suspension d'exécution des prestations, fin du contrat. Néanmoins, le lecteur y sera frappé par la variété de contrats particuliers analysés: diversité en raison de l'identité du salarié - travail domestique, des étudiants, des marins... - diversité, surtout, tenant à la finalité du contrat, à sa durée, ou encore, à sa précarité: contrat d'apprentissage, de travail intérimaire, contrat saisonnier, de suppléance, etc. Le souci d'encadrer la période d'essai d'exécution du contrat de travail est également marqué. En revanche, le contrôle judiciaire de sa résiliation ne permet pas d'envisager la réintégration: le contrat de travail «... reste résilié, même $\mathrm{p}$. ex. lorsque, par la suite le juge déciderait que les faits ayant donné lieu au licenciement ne sont pas assez graves pour être admis comme motif grave. Dans ce cas et aussi en cas de nonobservance 
des formalités requises en matière de motif grave et en cas de modification unilatérale de conditions de travail essentielles, la partie résiliante est tenue de payer une indemnité forfaitaire à l'autre partie (...)» (p. 190).

Le droit collectif du travail s'oeuvre naturellement sur la conquête et la protection de la liberté syndicale. L'auteur prend soin de situer le droit belge par rapport aux critères européens et de l'O.I.T. applicables. Or, la démarche revêt une importance particulière vu l'importance des avantages dont jouissent les organisations syndicales représentatives en Belgique. Ainsi, le monopole de conclure des conventions collectives au sens de la loi, «aussi bien sur le plan de l'entreprise et de la branche d'activité que sur le plan national» est-il réservé à ces associations (p. 230). Surtout, l'État associera-t-il exclusivement des associations à différentes structures de concertation professionnelle. En somme, selon l'auteur:

«... le principe d'organisation syndicale représentative a donné un tout autre aspect à la liberté syndicale. Il est sans doute à l'origine d'une inégalité de traitement entre les diverses organisations syndicales... Il convient cependant de souligner que la notion d'organisation syndicale représentative répond à la recherche d'un équilibre entre, d'une part, le principe de la liberté syndicale qui postule le pluralisme et l'égalité, et, d'autre part, l'intérêt collectif des travailleurs qui préconise autant que possible l'unité d'action. Le principe d'organisation syndicale représentative est d'autant plus défendable qu'il constitue dans une certaine mesure une application du principe démocratique de la majorité (...)» (p. 218).

L'ouvrage décrit la réalité des mouvements syndicaux et patronaux, souligne le refus traditionnel de la personnalité juridique de la part des organisations syndicales. Il expose l'organisation des relations entre employeur et travailleurs, du plan de l'entreprise - délégation syndicale, conseil d'entreprise et Comité de sécurité, d'hygiène et d'embellissement des lieux de travail, triptyque dont les deux premiers plans sont un reflet frappant de l'histoire - au plan de la branche d'activité - les commissions paritaires - et, enfin, au plan national entier - le Conseil national du travail. De l'énoncé détaillé, particulièrement limpide, de cette complexe réalité, ressort une impression d'interrelation des partenaires sociaux qui trouve son prolongement dans celui relatif au régime juridique de la convention collective. Régime des conventions collectives, devrait-on dire, car elles interviennent, de façon stratifiée, du niveau de l'entreprise, à celui de la branche professionnelle, et même par rapport à l'ensemble national tout enticr. L'autonomie des organisations d'employeurs et de travailleurs en ce qui a trait à la détermination des conditions de rémunération et de travail y est primordiale, l'Autorité ne s'(étant) vue attribuer qu'un rôle secondaire, et ce (sous réserve de certains phénomènes récents) entièrement dans la ligne de la tradition des relations de travail belges» (p. 273). Même étendue par Arrêté Royal à tous les travailleurs d'un vaste ensemble, une convention collective conclue au sein d'un organe paritaire et ayant acquis de ce fait une force obligatoire qui lui fera occuper la deuxième place, après la loi, dans l'ordre des dispositions impératives, demeurera foncièrement l'oeuvre des partenaires sociaux. De la convention résulte implicitement une obligation relative de paix sociale: «... non seulement l'interdiction (pour les parties contractantes) de prendre des mesures de lutte, mais l'obligation d'empêcher que leurs membres ne déclenchent un conflit dans le but d'obtenir une modification de la (convention collective)" (p. 284). Des pages finales exposent le régime juridique de la grève et du lock-out, moins usité: portée de cette obligation de paix, recours préalable à certains moyens de conciliation et effets sur le contrat de travail (réception graduelle de la théorie de la suspension).

En plus de livrer fort clairement, comme son titre l'indique, les aspects fondamentaux du droit du travail belge, l'ouvrage du professeur Blanpain sera particulièrement apprécié 
du spécialiste étranger du droit du travail en ce qu'il lui apportera la possibilité de saisir l'esprit général de cette organisation poussée des rapports entre partenaires sociaux qui a surtout caractérisé ce droit depuis l'aprèsguerre, de même que la nature des tensions nouvelles auxquelles il se trouve actuellement soumis, tensions qui connaissent de moins en moins de frontières.

\section{Pierre VERGE}

Université Laval

Work in the Changing Canadian Society, by Mervin Y.T. Chen and Thomas G. Regan, Toronto, Butterworths, 1985, pp. XIV + 289, ISBN 0-409-82335-X

This is a review of several vital social dimensions of work in contemporary Canada. It starts with the development of labour force influenced by the growing participation rate: in the period 1961-1981 it has grown from $55 \%$ to $65 \%$ in general, and from $29 \%$ to $66 \%$ among the women in the age group 25-34. The growth of services and the decline of the primary sector in the labour force allocation has also contributed to change. The next chapter deals with occupational choice. Unfortunately here is not considered how much the decisions of Canadians regarding their occupational careers actually match the needs and necessities of the Canadian economy exposed to the growing competition with other economies. In the chapter on socialization to work the mechanism of acquiring necessary skills and attitudes is well presented on professional or semi-professional examples. However, no attention is paid to the clash between egoism and collectivism. How much the mechanisms of socialization really contribute to the good citizenship? Under the conditions of an economic stress several occupational groups promote their own interests on expense of public interest, and this is an obviously better evidence of poor socialization in the broader sense than only the loyalty to one's own occupational group.
In the chapter on occupational careers some emphasis would be needed on the moral aspects and actual social utility what people are actually doing. Depending on the perspective on a given career we will see it much differently. For example, a much popular teacher from the deeper professional perspective may be just a failure even if he/she collects the best student evaluation scores for his/her cheap jokes. Several superficially successful occupational careers are actually damaging to the society instead of benefitting it when the career performers neglect some essential duties. Also the organizational aspect of careers would need to be better recognized. There is quite often a conflict between organizational loyalties and professional loyalties. People who fail from an organizational perspective may be heroes from a professional perspective. Dilemmas related to careers are quite often painful and the reader should be made aware of it. In complex organizations the careers are quite often much more unstable as may be concluded from the statement that «everyone in a formal organization has a stable set of expectations" (p. 92). Especially in the time of economic decline people have many good reasons to worry about their occupational careers and this aspect is definitely underestimated by the authors.

In the chapter on occupational mobility trends are exposed and justifications are reported regarding the allocation of manpower and the chances of advancement. Increasing size of social groupings leads to the multiplication and reinforcement of regulatory mechanisms. Work processes and work groups are increasingly fragmented (specialization). Mutual relations between working people are standardized. People differ in the nature of work tasks, prerequisites for entry, the work situation, and the type of social organization for the task. Education, income and prestige in mutual combination put people accordingly on the social hierarchy. Missing in this broad picture is the gap between aspirations and occupational realities much reinforced by mass advertisement, consumer orientation, easy entrance to educational channels and general per- 